REFUGE OF THE HONORED 



\title{
REFUGE OF THE HONORED
}

Social Organization in a Japanese

Retirement Community

\author{
Yasuhito Kinoshita \\ Christie $W$. Kiefer
}

University of California Press

Berkeley · Los Angeles · Oxford 
University of California Press

Berkeley and Los Angeles, California

University of California Press, Ltd.

Oxford, England

(C) 1992 by

The Regents of the University of California

\section{Library of Congress Cataloging-in-Publication Data}

Kinoshita, Yasuhito, 1953-

Refuge of the honored : social organization in a Japanese retirement community / Yasuhito Kinoshita, Christie W. Kiefer.

p. $\mathrm{cm}$.

Includes bibliographical references and index.

ISBN 0-520-07595-1 (alk. paper)

1. Retirement communities-Japan-Case studies.

2. Retirees-Japan-Attitudes-Case studies.

3. Aged-Japan-Attitudes-Case studies. I. Kiefer, Christie W. II. Title.

HQ1063.2.J3K56 1992

$305.26^{\prime} 0952-\mathrm{dc} 20$

Printed in the United States of America

$\begin{array}{lllllllll}9 & 8 & 7 & 6 & 5 & 4 & 3 & 2 & 1\end{array}$

The paper used in this publication meets the minimum requirements of American National Standard for Information Sciences-Permanence of Paper for Printed Library Materials, ANSI Z39.48-1984. 